\title{
VEKOSLAV GRMIČ (1923-2005) O LUTHROVI TEOLOGIJI
}

\section{Grmičevo razumevanje Luthrove teologije FANiKa KrajnC-VREČKo}

Slovenski teolog Vekoslav Grmič (1923-2005), eden naših najpomembnejših dogmatikov druge polovice 20. stoletja, je v slovenskem in srednjeevropskem prostoru zapustil trdno sled v razumevanju nauka Cerkve, ki je bil v iskanju večne resnice o Bogu skozi stoletja zaznamovan $\mathrm{z}$ različnimi razlagami posameznih vprašanj verovanja. Grmičeva teološka in miselna ustvarjalnost je temeljila na dialoškem razumevanju bivanja, mišljenja in delovanja sveta, ki se nenehno spreminja in v katerem mora tudi teologija iskati vedno nove izraze za svoje evangeljsko sporočilo. Prizadeval si je za posredovanje take teologije, ki bo ustrezala konkretnim življenjskim razmeram in bo upoštevala človeka v njegovem bivanjskem okolju ter v odnosu do Boga. V tem kontekstu se je, kot je poudaril njegov naslednik na Teološki fakulteti, profesor Avguštin Lah $(2018,165,175)$, ukvarjal tudi z zgodovinskimi vprašanji krščanske teologije in s svojo kritično držo do Cerkve povzemal ideje drugega vatikanskega koncila,

da naj Cerkev postane živo občestvo kot v prvih krščanskih časih oziroma da zaživi kot »Božje ljudstvo« [...], ki je tako v izrazu kot po vsebini prevladujoča tema v protestantski ekleziologiji. [...] Vekoslav Grmič, človek, teolog in mislec, ostaja kljub pomanjkljivostim simbol vernega, ustvarjalnega, doslednega, v človeka in njegovo sedanjo in prihodnjo srečo, iz katere se Bog ne sme izključiti, zazrtega človeka in profesorja.

Različna vrednotenja Grmičevega dela, ki so jih predstavili njegovi biografi, odražajo različna okolja, ki so sprejemala njegovo kritično 
teološko, družbeno, humanistično in antropološko misel, zato na tem mestu poleg Lahovega omenjamo zapis Cvetke Tóth, ki je predstavila Grmičeve razprave o protestantizmu.

\section{Grmičevo raziskovanje Trubarjeve teološke misli}

V svoji kritični, a dialoški in ekumensko naravnani drži do pojavov v sodobni Cerkvi se je Grmič soočal tudi s pojavi v protestantizmu 16. stoletja in nekaj svojih razprav namenil Primožu Trubarju, sistematično pa je predstavil tudi Luthrovo teologijo 16. stoletja ter osvetlil nekatere temeljne Luthrove premise, na katerih temelji sodobna protestantska teologija. O Grmiču kot poznavalcu slovenskega protestantizma je v pričujoči reviji pripravila daljšo razpravo že Cvetka Hedžet Tóth in med drugim zapisala (2014, 119-20):

Pozitivne pridobitve reformacije za nas, Slovence, povzema Grmič v tole pomembno oceno: »Izostren čut za svobodo in človekove pravice, za enakost pred Bogom vseh narodov in posameznih ljudi se je prebudil v Slovencih prav v času reformacije." Toda poslanstvo naših, slovenskih reformatorjev ni bilo lahko, nihče mu ni pel v zibelki uspavanke, rečeno s kakšno novejšo prispodobo. Brez svojega jezika ne bi mogli postati evropski narod.

Razen obravnave teološke govorice, ki je pomemben del Trubarjeve teologije, se Grmič ni ukvarjal z vprašanjem jezika, je pa Trubarjevo teologijo skušal postaviti v sistem in pri njem izpostavil vprašanje, ki se ga redko dotaknejo sodobni raziskovalci, namreč da je Trubarjevo teološko misel mogoče razumeti, če jo najprej postavimo v njen čas, se pravi predvsem, če v njej gledamo odgovor na razmere, ki so takrat vladale v Cerkvi.

Spoznati je mogoče predvsem njegovo zakoreninjenost $\mathrm{v}$ razmerah, $\mathrm{v}$ katerih je živel in deloval, in humanistične vplive, ki so ga že zgodaj izoblikovali in so ostali zanj vse življenje odločilni. [...] Imel je globoko zavest poslanstva, ki ga mora izvršiti, in zato se je čutil odgovornega za svoje 
delo. [...] Njegov humanizem je bil najtesneje povezan $\mathrm{z}$ njegovo religioznostjo in ljubeznijo do ubogega slovenskega ljudstva. (Grmič 1986, 136)

Ko je Trubarjevo teologijo skušal sistematično opredeliti, je pri njem iskal načela teološke misli in jih povzel v luči Trubarjeve osebnosti, njegovih ciljev in motivov, ki so ga vodili pri delu. Izpostavil je biblični, antropocentrični, dialoško-ekumenski, kritično-reformni ter duhovniški princip v Trubarjevem delu, ki je bilo, kot pravi Grmič, deloma pod vplivom drugih reformatorjev, deloma pa ga je odlikovala njegova samostojna teološka misel. (Grmič 1995, 251-257) Grmič nikjer ne trdi, da je Trubar izrazit lutrovec, zato bo poznavalcu Trubarjeve misli morda lažje osvetliti pogled na njegovo odvisnost od Luthrove teologije, ki jo v zadnjem času kategorično izpostavljajo nekateri avtorji, če prisluhnemo Grmičevi predstavitvi Luthrove teologije.

\section{Grmič in Luthrova teologija}

$\mathrm{V}$ nadaljevanju objavljamo dve pomembni Grmičevi razpravi o Luthru in njegovi teološki misli, ki sta izšli leta $1983 \mathrm{v}$ reviji Znamenje, in to Temeljni poudarki Luthrove teologije (1983b) ter Pogled sodobnega katoliškega teologa na Luthra (1983a). Kljub oddaljenosti objave obeh razprav se zdi Grmičevo razmišljanje povsem sodobno. Sam pri Luthru išče tiste vsebine njegove teološke misli, ki bi jih lahko prav tako pripisali avtorju samemu. Kot je o Grmiču dejal njegov naslednik Avguštin Lah $(2018,175)$,

Vekoslav Grmič, človek, teolog in mislec, ostaja kljub pomanjkljivostim simbol vernega, ustvarjalnega, doslednega, $v$ človeka in njegovo sedanjo in prihodnjo srečo, iz katere se Bog ne sme izključiti, zazrtega človeka in profesorja,

tako je Grmič zapisal o Luthru, namreč da je kljub pomanjkljivostim globoko zasidran v veri, cerkveni oče protestantizma, ki mu je šlo predvsem za človeka, in ki je znotraj Cerkve, tudi katoliške, s svojo teološko mislijo sprožil plaz, ki je skozi stoletja spremenil celotno krščansko teološko misel. Obe razpravi moremo uvrstiti med redke tehtne teološke 
razprave o reformatorju Luthru, ki so izšle pri nas, zato ju lahko z razdalje skorajda štiridesetih let ponovno objektivno presodimo.

\section{LITERATURA}

Grmič, Vekoslav. 1983a. "Pogled sodobnega katoliškega teologa na Luthra.« Znamenje 13 (6): 501-508.

---. 1983b. »Temeljni poudarki Luthrove teologije.» Znamenje 13 (5): 355-362.

---. 1986. »Korenine Trubarjeve teološke misli.« V 16. stoletje v slovenskem jeziku, književnosti in kulturi: Mednarodni simpozij v Ljubljani od 27. do 29. junija 1984, ur. Breda Pogorelec in Jože Koruza, 129-138. Ljubljana: Filozofska fakulteta.

---. 1995. »Prinzipien von Trubers theologischen Denken.« V Ein leben zwischen Laibach und Tübingen. Primus Truber und seine Zeit, ur. Rolf-Dieter Kluge, 251-257. München: Otto Sagner.

Hedžet Tóth, Cvetka. 2014. »Vekoslav Grmič o protestantizmu.«Stati inu obstati 10 (19-20): 119-46.

Lah, Avguštin. 2018. »Teologija v dialogu s človekom, ki mu služi.« Edinost in dialog 73 (1-2): 163-75.

\section{Temeljni poudarki Luthrove teologije VeKosLaV Grmič}

Ob 50o-letnici rojstva reformatorja Martina Luthra je prav, da se nekoliko ustavimo ob njegovi teološki misli. Misel, ki je v času njegovega pogumnega nastopa pomenila povod za usoden dogodek v zgodovini zahodnega krščanstva, danes nikakor ni tako nenavadna in izzivalna, kakor je bila takrat. Marsikatero Luthrovo spoznanje se je namreč pozneje tako ali drugače uveljavilo tudi v katoliški teologiji. Posebej za čas po drugem vatikanskem cerkvenem zboru bi smeli to upravičeno trditi. Res pa je tudi, da je Luther na neki način bil že naravnost navzoč na tem cerkvenem zboru in da je njegova misel od svojih začetkov do danes doživela precejšnjo preobrazbo. Sploh bi smeli reči, da je Luther dal

1 Razprava je bila izdana v Znamenje 13 (5): 355-62. Za namene pričujoče objave je bila lektorirana in uredniško dopolnjena. 
s svojimi pogledi predvsem pobude za vedno nova razmišljanja in poglobitve teološke misli. A zaradi tega njegov pomen ni nič manjši.

Seveda ne smemo misliti, da je Luthrova teološka misel vzniknila naenkrat, neodvisno od tistih, ki so ji s svojimi pogledi pripravljali pot, in od razmer, ki so določale splošno miselnost tistega časa. Tudi Luthra je mogoče razumeti samo $v$ tesni povezavi s tedanjimi razmerami, in sicer ne samo v Cerkvi, temveč v svetu sploh. Martin Luther je odgovarjal na znamenja časa, na razmere in njihove zahteve. Srednjeveška miselnost je postala ovira za razvojno pot človeštva v novi vek, zato je čas naravnost izzival $\mathrm{k}$ novim pogledom. $\mathrm{V}$ Luthru se je na izreden način dogajalo vse tisto, kar se je dogajalo zunaj njega, v njem je to na poseben način odmevalo in tako usmerjalo njegovega duha. Samo tako je mogoče razumeti, zakaj je Luthrovo delo imelo uspeh, kakršnega njegovi predhodniki niso imeli, čeprav so si še v nekem pogledu bolj prizadevali, da bi uspeli. Razmere so bile ugodne, čas je dozorel.

A kljub temu si je Luthrova misel s težavo utirala pot, kljub temu je Luther nastopal kot prerok in doživljal usodo preroka, se pravi, da je imel opraviti s hudimi nasprotovanji in je moral premagati nešteto ovir, ki so hotele za vsako ceno onemogočiti njegova prizadevanja. Potrebna je bila izredna volja, potreben je bil tudi izreden talent. In vse to je Luther bil. Razen tega je reformator imel še globoko religiozno zavest o svojem poslanstvu. Joseph Lortz $(1982,363)$ pravi:

O enem si morajo vsi opisi Luthra na katerikoli strani biti edini, da je namreč bil pred vsem drugim, kar ga je odlikovalo, religiozen človek.

Luther ni izdelal nekega teološkega sistema, ki bi obsegal vsa pomembna teološka vprašanja in jih v logičnem zaporedju obravnaval. Luther je sicer bil tudi profesor teologije, vendar so njegova teoretična spoznanja bila vedno usmerjena $\mathrm{v}$ prakso in so bila tesno povezana $\mathrm{z}$ osebnim verskim izkustvom, kar jim je dajalo pečat življenjskosti in izredno prepričljivost. $Z$ nekaterimi središčnimi mislimi pa je kljub temu jasno nakazal smer svojega razmišljanja in svoje izsledke tudi glede vprašanj, ki jih sploh ni posebej načenjal. Mislim, da je prav v tem teološkem obnebju, ki ga je s svojimi mislimi orisal, veličina njegove teolo- 
gije. Njena veličina je, tako bi lahko rekli, v žarišču, iz katerega je mogoče zaslutiti vse tisto, česar ni naravnost povedal, a je nujno povezano s tem žariščem njegovega teološkega razmišljanja.

\section{Luthrov teološki obraz}

Walter von Loewenich imenuje Luthra pridigarja in dušnega pastirja, profesorja in »cerkvenega očeta « $(1982,336)$. Zavedal se je svojega poslanstva, zato je to poslanstvo tudi zavzeto izvrševal, posebno še $\mathrm{z}$ oznanjevanjem.

Tako po obsegu kakor po vsebini so bile Luthrove pridige nekaj, v kar je položil vse svoje sile. Ohranjenih je več kakor dva tisoč njegovih pridig. V njih je razlagal predvsem svetopisemske odlomke. Vendar to niso bile homilije v ožjem pomenu, ker se je pogosto omejil v svoji razlagi le na nekatere besede ali vrstice iz celotnega bibličnega odlomka. Znova in znova se je ustavljal ob vprašanju Kristusa in vere. Hotel je pač čim nazorneje iz Svetega pisma izvajati in dokazati svoje nazore, ki so izhajali tudi iz osebnega izkustva. Govoril je ljudem »od duše do duše«.

Posebno pozornost je Luther posvečal duhovni tolažbi. V svojih pridigah je znal na izreden način tolažiti in vlivati ljudem upanje. Bolniki in tisti, ki so trpeli zaradi dvomov in skušnjav, so bili vedno deležni njegove dušnopastirske skrbi in ljubezni. Hotel jim je po svojih močeh res pomagati. V ta namen je znal prepričljivo uporabljati Sveto pismo Božjo besedo in tolažbo.

Svoje teološke poglede je dosledno izvajal iz Svetega pisma in zato se je kot teolog ukvarjal predvsem s preučevanjem Svetega pisma. O cerkvenih zborih je jasno izjavil (Luther v Loewenich 1982, 352):

Koncil nima nobene pravice, da bi določal nove člene vere, temveč mora samo staro vero braniti pred krivo vero.

Ni imel namena ustanavljati novo Cerkev, temveč je hotel ohraniti kontinuiteto $\mathrm{z}$ resnično, pravo, staro Cerkvijo. In prav zaradi tega je tako močno poudarjal pomen Svetega pisma in njegov primat v odnosu do Cerkve. Po njegovem mnenju evangelija ne sprejemamo kot Božjo be- 
sedo zato, ker Cerkev tako uči, temveč zato, ker čutimo, da je Božja beseda. (po Loewenich 1982, 354)

Luther je s svojim delovanjem postal nekakšen »cerkveni oče«. Njegovi nasprotniki so ga imenovali zaničljivo "protipapeža«, čeprav kaj takšnega ni želel nikdar biti. Res pa je, da je njegova avtoriteta bila izredna zaradi njegove verske genialnosti, genialnosti na verskem področju, v verskih pogledih in zamislih. In tako je postal nehote avtoriteta v teoloških in cerkvenih vprašanjih, se pravi, da je postal »cerkveni oče reformacije«. (Loewenich 1982, 357) Ob 400-letnici njegovega rojstva je Adolf von Harnack dejal (v Fridell 1982, 275):

Pot k cilju nam je po dolgi noči pokazal mož, ki si o njem smemo drzniti reči: bil je reformacija.

A kljub temu je bil Luther na zunaj le profesor in "mestni župnik«. Imel je tedaj veliko moralno avtoriteto med verniki. Šlo je za prepričljivost, s katero je med ljudmi nastopal, za izredno moč njegovega duha, ki jo je izžareval. Bil je, kratko povedano, nenavadna religiozna osebnost. Samo tako je mogoče razložiti, kar se je zgodilo, ne da bi sam to tudi hotel, da si je namreč pridobil ugled med svojimi somišljeniki, kakršnega ni imel nihče drug.

Bil je zakoreninjen v starem, zato je bil sposoben prinesti tisto novo, kar je bilo najpotrebnejše. Sam je živo čutil, kako je bilo to novo potrebno.

Kdor hoče postati Pavel, je moral prej biti Savel, da, v temelju mora ostati vse svoje življenje del Savla. Samo iz tega nenehnega boja zoper samega sebe in svojo preteklost je mogoče črpati moč v boju za prihodnost. (Luther v Fridell 1982, 276)

In takšen je bil Luther, zato tudi v marsičem ni napravil koraka, ki bi ga v skladu z miselnostjo prihajajočega časa pričakovali, temveč je ostal kot Mojzes v puščavi in drugim pokazal pot v »obljubljeno deželo.« Ostal je nekako na prehodu iz starega v novo, vendar je tako odločno pokazal na novo, da ni bilo nobenega dvoma, v katero smer naj gredo tisti, ki so prihajali za njim in so se oplajali z njegovim duhom. Moderna misel pa se je pri Luthru uveljavila predvsem v treh smereh: v smeri in- 
dividualizma in subjektivizma, $\mathrm{v}$ smeri demokracije in $\mathrm{v}$ smeri svetnega, tostranskega ali horizontalnega.

$\mathrm{V}$ svojih razmišljanjih je izhajal Luther iz osebnega zavestnega in podzavestnega strahu v odnosu do Boga in njegovega zakona, njegove pravičnosti, njegove jeze zaradi človekove, torej tudi lastne grešnosti. Rekli bi lahko, da je s svojim teološkim razmišljanjem hkrati razlagal Sveto pismo in razreševal tisto, kar ga je vznemirjalo, kar mu je pomenilo kot religioznemu človeku žgoče življenjsko vprašanje.

O Luthru ima popolno veljavo sodba:

Kdorkoli preučuje Luthrovo življenje, ga mora kljub mnogim zamejitvam vzljubiti. Odločilno pa je, da še tudi današnja generacija sprejema njegovo preroško poslanstvo. (Loewenich 1982, 370)

\section{Bog in človek}

Za Luthra je bilo vprašanje človeka, ki ga je obravnaval, najtesneje povezano $\mathrm{z}$ vprašanjem Boga, se pravi, da mu je šlo za vprašanje človeka pred Bogom. Vprašanje človeka pred Bogom pa je nujno včlenjevalo dve vprašanji: kakšen je Bog za človeka in kakšen je človek pred Bogom?

Na prvo vprašanje je iskal Luther odgovor v Svetem pismu. A slednje govori o dveh različnih podobah Boga. Prva je navzoča predvsem v Svetem Pismu Stare zaveze, druga pa v evangeliju. Medtem ko nam Sveto pismo Stare zaveze znova in znova govori o Bogu, ki daje zapovedi in prepovedi, ki je strogo pravičen in zato vse hudo tudi kaznuje, ki je tedaj pravičen sodnik in maščevalec krivic, najdemo v evangeliju podobo Boga, ki je postal človek, trpel in umrl za človeka in njegove grehe ter tako razodel svojo ljubezen in usmiljenje. Seveda pa Luther ni spregledal, da Sveto pismo Stare zaveze pozna tudi Božje usmiljenje in da evangelij govori tudi o Božji pravičnosti. A kljub temu je v evangeliju in Pavlovih pismih našel odgovor, kako je mogoče najti usmiljenega Boga, kako se je mogoče izogniti Božji jezi in biti deležen Božjega usmiljenja.

Odgovor na drugo vprašanje je Luther izkustveno doživljal v sebi, a tudi Sveto pismo mu ga je dalo. Ta odgovor se je glasil, da je človek grešnik, in sicer ne samo zaradi tega, ker vedno znova greši, temveč pred- 
vsem zato, ker je njegova narava po grehu (izvirnem grehu) pokvarjena, sebična, namesto da bi bila usmerjena k ljubezni. Človek je tako po svoji naravi Božji nasprotnik in zato je napetost med Bogom in vsem, kar je grešno, hkrati napetost med Bogom in človekom.

Pravični Bog ne more drugače, kakor da obsoja človeka, ki je grešnik in njegov nasprotnik. Vendar, kakor smo že rekli, se je Bog v Kristusu razodel kot usmiljeni Bog, ki pa je seveda kljub temu tudi pravičen. Kako je potem mogoče najti izhod iz okolja Božje jeze in obsodbe? Samo tako, da človek prizna svojo grešnost in soglaša $\mathrm{z}$ Božjo sodbo. To je prvo, kar je potrebno, kar lahko grešnika reši, kakor zagotavlja Božja beseda v evangeliju. Drugo, kar je potrebno, pa je vera v Jezusa Kristusa in zaupanje $v$ njegovo odrešilno delo, vera in zaupanje, da bo Bog zaradi Jezusa Kristusa človeku naklonil svoje usmiljenje, da mu ne bo prišteval greha, temveč Kristusovo zadoščenje, Kristusovo pravičnost, Kristusovo milost.

Božja pravičnost se tudi po nauku sv. Pavla razodeva kot pravičnost, ki človeka rešuje, če le veruje in zaupa v Božje usmiljenje. Bog sam človeka sodi in se ga hkrati usmili, Božja sodba se javlja kot Božja ljubezen in Božje usmiljenje. Človekova nemoč se zaradi Božje milosti rešuje v Božji moči. Strah se spreminja v zaupanje in ljubezen.

Človek sam si ne more pomagati, ker je pač grešnik. Pomaga mu lahko samo Bog, ki se ga usmili zaradi Jezusa Kristusa. Takšno je evangeljsko oznanilo, odrešujoče, veselo oznanilo.

Ob razmišljanju o Bogu »za nas« in »človeku pred Bogom» je Luther na podlagi Svetega pisma našel odgovor na eksistencialno in eksistencielno pomembno vprašanje, ki ga je tako vznemirjalo, da se ni mogel umiriti, dokler ni prišel do spoznanja, da kljub vsemu, kljub grešnosti, ki jo je čutil v sebi, lahko zaupa v Boga. Ne smemo pa misliti, da je v skladu z Luthrovimi pogledi mogoče na tak način priti do popolnega miru. Mir je v tem pogledu sad nenehnega nemirnega iskanja ali boja za zaupanje v Boga ob misli na Božjo pravičnost, ki se sicer javlja v Božjem usmiljenju zaradi Jezusa Kristusa, ki pa je kljub temu pravičnost, kakor je človek grešnik kljub temu, da se ga Bog usmili, da mu prišteva pravičnost Jezusa Kristusa. Vera, kakor jo je oznanjal Luther, je tedaj nekaj hudo resnega. 
Čeprav je Luther v svoji teologiji še tako soteriološko mislil in postavljal v središče opravičenje človeka samo zaradi vere v Božjo oprostitev, se resničnost in resnost Božje sodbe nista izgubili, temveč ju je treba vedno znova v veri in zaupanju v Kristusa, milostnega Boga, premagati. [...] Božja jeza ni nikakršna domišljija, temveč je v življenju in zgodovini delujoča moč, pred katero je treba bežati k ljubezni, kakršna se je razodela v Jezusu Kristusu. (Lohse 1982, 177)

Človek, tako bi smeli reči, mora pred Bogom vedno znova iskati zavetje pri Bogu, pred Bogom se zateči k Bogu. V prvem primeru mislimo na Boga postave, v drugem pa na Boga usmiljenja, evangelija.

Tako je Luther našel tisto odrešujočo Arhimedovo točko svojega teološkega razmišljanja, s pomočjo katere je premagal na videz nepremostljive težave in hkrati postavil pod vprašaj nekatera spoznanja takrat splošno razširjene teološke misli. Zato tudi ni čudno, da je vprašanje opravičenja ostalo za Luthra vedno osrednje vprašanje in da je odgovor na to vprašanje, namreč opravičenje po milosti iz vere, dobil naziv »articulus stantis et cadentis ecclesiae«(Pesch 1982, 43).

\section{Dialektika Luthrove teološke misli}

V Luthrovi teološki misli najdemo vedno znova trditve, ki si na prvi pogled nasprotujejo. To so paradoksi, ki v resnici pokažejo, da gre za spoznanja, izkustva, kakršna so značilna za Sveto pismo. Verska izkustva je namreč težko izraziti z besedami in jih osvetliti le s pojmi, ki imajo isti pomen, osvetliti samo z enega vidika. Lahko bi tudi rekli, da imajo izrazi, s katerimi skušamo povedati vsebino verskega izkustva, vedno presežen pomen, se pravi, da vsebujejo večkrat celo nekaj, kar nam more povedati pojem z nasprotnim pomenom. Gre pač za skrivnosti, ki presegajo človeški razum in njegovo zmožnost izražanja.

V prejšnjem poglavju smo že lahko zasledili paradoksne trditve $\mathrm{v}$ Luthrovem razmišljanju, ko združuje dve različni podobi Boga - podobo Boga postave in podobo Boga evangelija -, zato pa tudi Božjo jezo in pravičnost $\mathrm{z}$ Božjo ljubeznijo in usmiljenjem. Prav tako govori o strahu, ki človeka navdaja v odnosu do Boga, hkrati pa o zaupanju in ljubez- 
ni človeka pred Bogom. Podobno velja za trditev, da more človek doseči Božje usmiljenje le, če prizna svojo grešnost, čeprav je grešnost nekaj, kar je Bogu nasprotno.

Predvsem pa je dialektika Luthrove teološke misli opazna najprej kot enotnost postave/zakona in evangelija. Ne glede na Staro in Novo zave$z o \mathrm{v}$ tem pogledu, na podobo Boga, ki je značilna predvsem za Staro za$v e z o$, in drugo, ki jo razberemo iz Nove zaveze, lahko izrazimo to dialektiko z mislijo, da po Luthrovem globokem prepričanju Bog deluje »sub contario«, se pravi, da je v njegovi sodbi navzoča in se uveljavlja milost, v njegovi pravičnosti usmiljenje.

Dalje je pomembna dialektika, kadar Luther govori o verskem spoznanju in zavrača možnost razuma, se pravi, da je razum slep, in ga imenuje "hudičevo vlačugo" (v Lohse 1982, 166). Človeški razum je namreč odvisen od volje, se pravi, da človek spozna o Bogu tisto, kar hoče, ker je pač Bog za razum sam nedoumljiv in nedosegljiv. Volja sama pa je prizadeta zaradi človekove grešnosti in tako je človekova podoba o Bogu, kolikor je plod naravnega spoznanja, zmaličena. Luther zato (v Lohse 1982, 167) pravi:

Čim bolj se skušaš opirati na razum, tem bolj se oddaljiš od Boga.

Kljub temu pa reformator pripisuje razumu zmožnost, da spozna o Bogu tisto, kar Bog ni, da je zato njegova dejavnost pomembna, kolikor človeka odpira za Božjo presežnost in Božje razodetje. Le vera more osvoboditi razum, tako da je $\mathrm{v}$ resnici sposoben spoznavati resnico, tudi Boga, in le milost more prav uravnavati človekovo hotenje in spoznanje, kadar gre za pot $\mathrm{k}$ Bogu. Razum tedaj je in ni sposoben spoznati Boga. Odvisno je od tega, kako gledamo na razum, s katerega vidika presojamo njegovo sposobnost, kaj v izraz sposobnost polagamo.

Predvsem pa moramo omeniti na tem mestu dialektiko, ki je v izra$\mathrm{zu}$ »simul iustus et pecator «. Izraz hoče povedati, da je tudi človek, ki je deležen Božjega usmiljenja, ki je opravičen iz milosti po veri ali iz vere po milosti, še vedno grešnik. In čim bolj prizna, da je grešnik, tem bolj se odpre Božji milosti, tem bolj je deležen Božjega usmiljenja. Luther (v Hirsch 1963, 123) pove naravnost: 
Opravičenje (iustificari) človeka razumemo mi takole: človek še ni pravičen (nondum esse iustum), temveč je na potu ali $\mathrm{v}$ teku $\mathrm{k}$ pravičnosti. Zato je še vsak človek grešnik, kateri je bil opravičen, a se kljub temu ima (reputatur) za povsem in popolnoma pravičnega zaradi Božjega odpuščanja in usmiljenja.

Seveda je ta misel še bolj razumljiva, kolikor upoštevamo Luthrovo prepričanje, da se človeku prišteva Kristusova milost, Kristusova pravičnost, čeprav zopet to ni vsa resnica, kakor jo pozna reformator.

Naposled je dialektika navzoča tudi v Luthrovih nazorih o dobrih delih v odnosu do vere. Čeprav človeka opravičuje samo vera, kljub temu Luther ne zanemarja pomena dobrih del. Z ene strani pravi, da človek tudi v dobrih delih išče samega sebe, kolikor se zanaša na dobra dela, namesto da bi zaupal predvsem v Božje usmiljenje. Z druge strani pa (v Hirsch 1963, 122) pove:

Če smo bili zastonj (gratis) opravičeni, potem opravljamo dela ali še bolje: Kristus dela vse v nas. Če pa dela ne sledijo, potem je nedvomno, da ni takšne vere v Kristusa (hanc fidem Kristi) v našem srcu, temveč je v njem ona mrtva, se pravi pridobljena vera.

V tej dialektiki Luthrove teološke misli se na poseben način pokažeta njena globina in njena bivanjska razsežnost ali življenjskost. To je zares misel religioznega človeka, ki se bojuje za trdnost, zaupnost in čim popolnejšo izraznost vere, kakršno najdemo tudi v evangeljskem ali sploh bibličnem sporočilu.

"Sola scriptura, sola gratia, sola fides, solus Christus"

Po vsem tem bi že mogli izraziti Luthrove temeljne teološke misli ali temeljno teološko spoznanje s pojmi sola scriptura, sola gratia, sola fides, solus Christus, čeprav ne smemo teh pojmov jemati tako, da bi izključevali zaradi izraza »solus« vse drugo. Sicer pa nam takšno razumevanje teh izrazov narekuje tudi dialektika, ki smo jo našli v Luthrovi teologiji.

Izraz »sola scriptura " pomeni, da je Luther svojo teologijo zidal na Svetem pismu in da mu je Sveto pismo pomenilo najvišjo avtoriteto v 
vprašanjih vere in teologije, $v$ nekem pogledu edino avtoriteto. Niti koncil niti papež, kakor smo že omenili, ne moreta odločati o tem, kaj naj verujemo, temveč pripada ta pravica neposredno Svetemu pismu. Sveto pismo je tako popolna Božja beseda, »ut sit ipsa per sese certissima, facillima, apertissima, sui ipsus interpres, omnium omnia probans, iudicans et illuminans." (v Hirsch 1963, 85) Sveto pismo je z Luthrom dobilo tisto mesto v teologiji, kakor ga je imelo v času cerkvenih očetov. A Luther je kljub temu poudarjal tudi pomen izročila, posebno še tistega, ki se je uveljavilo na koncilih.

Izraza »sola fides« in »sola gratia» imata poseben pomen v njegovi teološki razlagi opravičenja. $\mathrm{V}$ resnici pa je ta njegova teološka misel trdno zasidrana v pismih apostola Pavla, ki prav tako poudarja pomen vere in milosti za opravičenje. Luther (v Hirsch 1963, 134) pravi naravnost: "Ni pravičen tisti, ki veliko dela, temveč tisti, ki brez del trdno veruje.« A te izjave ne smemo jemati ločeno od tistih njegovih besed, s katerimi ponovno ovrednoti tudi človekova dela. Zato bi smeli reči, da hoče Luther človeka samo odvrniti od tega, da bi se zanašal na svoje zasluge, na spolnjevanje predpisov, in bi mislil, da mu Bog nekaj dolguje, da mu mora nakloniti svoje usmiljenje. Vera je namreč plod Božje milosti, Božje ljubezni, Božje svobodne odločitve.

Ima pa izraz »sola fides « tudi svoj pomen, kadar govori o spoznanju Boga, kakor smo že omenili. A tudiv tem pogledu ni ta izraz izključevalen, tako da bi odrekal razumu vsako sposobnost.

Z izrazom "solus Christus" povzema Luther vse ostale izraze, ki smo jih navedli, ki na poseben način določujejo njegovo teološko misel. Konec koncev namreč vsi ti izrazi kažejo na Kristusa in dosegajo svoj polni pomen prav v Kristusu kot učlovečenem Bogu in Odrešeniku, $v$ njegovem odrešilnem delu. Luther pravi zato o Svetem pismu (v Lohse 1982, 165): »Svetega pisma ne smemo tolmačiti drugače kakor tako, da človek ni nič in da je samo Kristus vse.« Smeli bi tedaj trditi, da ima izraz »solus Christus « še najbolj izključevalen pomen, čeprav zopet ne smemo zaradi tega podcenjevati človeka in njegovega sodelovanja $s$ Kristusom, ki Luthru nikakor ni bilo popolnoma tuje, saj je imel do sveta in svetnih stvari vendarle zelo pozitiven odnos in je gledal v člo- 
vekovem delu službo Bogu in hojo za Kristusom. Seveda pa je človeku potrebna naravnanost h Kristusu po milosti, po veri, tako da potem Kristus v njem deluje. Zanimivo je prav tako, da je Luthrovo razmišljanje kljub tako izrednemu poudarku na veri, milosti in Kristusu dalo spodbudo za tostransko, horizontalno usmerjeno krščanstvo, medtem ko je nekoliko drugače usmerjena »katoliška« teološka misel vodila v krščanski vertikalizem.

\section{Teologija križa}

Luther sam je svojo teologijo ali teološko smer imenoval »teologija križa«. Zanj je krščansko življenje predvsem življenje križa, se pravi, da se v njem uresničuje Kristusovo trpljenje in umiranje. Vendar to ne pomeni toliko posnemanja Kristusa, temveč daje Bog človeku milost, da sprejme križ in sodbo nad grehom, ki jo križ pomeni. Prav križ namreč človeka dvigne k Bogu. »Za Boga je značilno, da vse podre in uniči, preden svoje podari, kakor je zapisano: 'Gospod življenje jemlje in daje, vodi v podzemlje in zopet nazaj pripelje' (1 Sam 2,6)." (Hacker $1966,100)$ Luther v nadaljevanju navaja Pavlov nauk, ki tudi ponovno govori o trpljenju in umiranju s Kristusom. Prav tako pa stoji s to mislijo trdno na evangeljskih tleh, saj tudi Kristus govori (Mt 16,24-25) o križu, ki ga mora človek sprejeti in za njim nositi, če hoče za njim priti:

Če hoče kdo priti za menoj, naj se odpove sam sebi in vzame svoj križ ter hodi za menoj. Zakaj kdor hoče svoje življenje rešiti, ga bo izgubil. Kdor pa svoje življenje zaradi mene izgubi, ga bo našel.

Tako reformator (Luther v Hacher 1966, 99) tudi pove:

Drugi (oltar) je mistični Kristusov križ. Na njem moramo biti vsi darovani.

Iz teologije križa izhaja praktičen sklep za življenje po veri, ki ga Luther izrazi z besedo "ponižnost« ali »samoponižanje«. Ponižnost izvira iz deležnosti pri križu - Kristusovem križu. Če hoče človek pred Bogom živeti, se mora pustiti kot Kristus na neki način od Boga uni- 
čiti, in sicer po trpljenju, po samoobtožbi, tako da sprejme Božjo sodbo nad grehom, se pravi, da postane ponižen, v nekem oziru kakor nič. (Pesch 1982, 89)

Ponižnost se kaže v različnih oblikah in včlenjuje odpoved, priznanje nemoči in grešnosti, skromnost, zaupanje v Boga in Božjo moč, zaupanje v Božje usmiljenje kljub zavesti lastne nevrednosti. Ponižnost je za Luthra temeljna sestavina vere. Brez ponižnosti ni vere v pravem pomenu besede. Brez ponižnosti ni mogoče imeti pristne podobe o Bogu in prave sodbe o sebi, zato pa tudi ne pravilnega razmerja do Boga.

Luthrova religioznost se s temi mislimi pokaže $\mathrm{v}$ posebno izraziti in pristni podobi. Imele pa so te misli tudi izreden pomen za druge njegove nazore in praktične odločitve. Zato je imel Luther prav, ko je pripisoval poseben pomen teologiji križa in ponižnosti kot bistveni sestavini krščanskega verovanja, krščanskega življenja. Teologija križa je tako dobila še določnejše poteze. Vendar tudi teologije križa ni mogoče prav razumeti, če ne upoštevamo dialektike, ki je navzoča $v$ Luthrovi teološki misli nasploh, ki tedaj omogoča pravilno razumevanje njegovih spoznanj.

\section{Sklep}

Takšni so temeljni poudarki v Luthrovi teologiji. Ti poudarki sicer niso vsi nekaj povsem novega, saj je marsikaterega od njih mogoče najti pri cerkvenih očetih, posebno še pri Avguštinu, čeprav so morda izraženi nekoliko drugače kakor pri Luthru. To tudi ni nič nenavadnega, če pomislimo, kako si je Luther prizadeval, da bi s svojo teološko mislijo ostal čim bolj zvest razlagalec Svetega pisma, posebno še evangelija in Pavlovih pisem. Ker pa je tudi Luther bil otrok svojega časa, na katerega so vplivali takratni miselni tokovi in so ga sploh oblikovale takratne razmere, ni čudno, če so njegova spoznanja časovno obarvana in zamejena, če so njegovi poudarki v teologiji pogosto enostranski, posebno še glede prav tako enostranskih poudarkov pri tistih, ki so nasprotovali njegovim reformatorskim težnjam. Na vsak način pa moramo pri Luthru priznati izreden pomen, ki ga ima zaradi mnogih pobud za razvoj in poglobitev teološke misli vse do danes. 
Mislim, da se po vsem tem lahko pridružimo sodbi kardinala Willebrandsa, ki jo je izrekel na zborovanju v Evianu pri Ženevi leta 1970. Takole je dejal (v Pesch 1982, 272):

Na zborovanju, ki ima za temo »Poslanstvo za svet«, je dobro, da se spomnimo moža, ki mu je bilo opravičenje »articulus stantis et cadentis ecclesiae«. V tem pogledu nam more biti skupen učitelj, da namreč mora Bog ostati Gospod in da je naš najpomembnejši odgovor popolno zaupanje in češčenje Boga.

Kakor pa smo mogli spoznati iz tega razmišljanja o temeljnih poudarkih Luthrove teologije, nam je lahko Luther še v marsičem drugem skupen učitelj, če ga le poskušamo brez predsodkov razumeti. Zato moremo biti veseli vseh premikov, ki so danes vidni v katoliških vrstah glede vrednotenja Luthra in njegovega dela. Katoličani smo postali pravičnejši v svojih pogledih na tega velikega reformatorja. Ta ugotovitev je pomembna ob 50o-letnici njegovega rojstva, čeprav izraža nekaj, kar se je zgodilo šele po več stoletjih.

\section{LITERATURA}

Friedell, Egon. 1982. Kulturgeschichte der Neuzeit 1. München: Deutscher Taschenbuch Verlag.

Hacker, Paul. 1966. Das Ich im Glauben bei Martin Luther: Der Ursprung der anthropozentrischen Religion. Gradec, Dunaj in Köln: Styria

Hirsch, Emanuel. 1963. Hilfsbuch zum Studium der Dogmatik. Berlin: Walter de Gruyter.

Lohse, Bernhard. 1982. Martin Luther: Eine Einführung in sein Leben und sein Werk. München: Beck.

Lortz, Joseph. 1982. Die Reformation in Deutschland. Freiburg, Basel in Dunaj: Herder. Loewenich, Walter von. 1982. Martin Luther: Der Mann und das Werk. München: List. Pesch, Otto Hermann. 1982. Hinführung zu Luther. Mainz: Grünewald. 


\section{Pogled sodobnega katoliškega teologa na Luthra \\ VEKOSLAV GRMič}

Ob pogledu na Luthra, kakršen naj bi bil glede na naslov mojega razmišljanja, se mi vsiljuje občutek nemoči, da bi podal tisto podobo, ki bi ustrezno izrazila vsebino Luthrove osebnosti, njegove misli in njegovega dela. Martin Luther je takšna osebnost, da vsak poskus, ki ga želi iskreno prikazati, nujno ostane okrnjeno, nedokončano in nepopolno delo, torzo. Za moj skromen razmislek ima to spoznanje še poseben pomen.

Zastavlja pa se mi ta trenutek tudi vprašanje, kakšen pomen naj dam izrazu »sodoben«. Človek je namreč lahko formalno sodoben, tako da pač ravna v skladu s splošno veljavnimi pravili svojega časa in se ravna po večini. Lahko pa je tudi vsebinsko sodoben in upošteva ustvarjalni tok človeške misli in njene dosežke ter si prizadeva, da bi čim bolj prisluhnil znamenjem časa in nanje odgovoril. Takšna drža ga seveda more narediti v nekem pogledu celo nesodobnega, ker pač za mnoge prehiteva čas.

Slednjič ni tako preprosto prilaščati si naziv »katoliški teolog «. Dobro vemo, da imamo danes tudi v katoliški Cerkvi različne teološke smeri, ki so včasih vsaj tako različne kakor teologije različnih krščanskih veroizpovedi. Te smeri so kdaj pa kdaj tudi močno izključevalne, tako da le s težavo priznavajo druga drugi katoliško oznako. Zato večkrat naletimo na očitke, ki komu odrekajo, da bi bil katoliški teolog, čeprav mu še na misel ne pride, da bi to ne želel biti. Pogosto namreč za pravovernost ni dovolj, da človek ni v nasprotju $\mathrm{z}$ dogmatičnimi opredelitvami Cerkve, cerkvenega učiteljstva, temveč bi nekateri hoteli, da bi se vsi teologi držali tudi iste teološke smeri, iste šole in celo zagovarjali isto "politično prepričanje« ali se vsaj vzdržali naklonjenosti tistim gibanjem, ki jih je papež Janez XXIII. imel v mislih v okrožnici Pacem in terris in jim kljub svetovnonazorskim razlikam $\mathrm{v}$ primeri $\mathrm{s}$ krščanstvom izrekel priznanje.

2 Razprava je bila izdana v Znamenje 13 (6): 501-7. Za namene pričujoče objave je bila lektorirana in uredniško dopolnjena. 
Kljub vsem tem pomislekom in težavam pa me veseli posvetiti nekaj misli Luthru v tem jubilejnem letu prav v okviru nakazane teme. Povedal bom pač tisto, kar mislim, o čemer sem prepričan, ne da bi s tem hotel reči, da bodo to samo moje misli in moje sodbe. Koliko bo pa to za koga katoliško in sodobno, pa je seveda drugo vprašanje. Tolaži me misel teologa Heinza Zahrnta, da je teologija precej nehvaležna veda in da človeku ne prinaša rada zunanje sreče in zunanjega veselja (Zahrnt 1977, 413).

Luthrovo delo ni bilo lahko. Hotel je reformirati Cerkev in to njegovo plemenito hotenje ga sicer zaradi zaščite, ki so mu jo nudili nemški knezi, ni vodilo na grmado, vendar pa mu je kljub temu prineslo veliko gorja in ga izrinilo iz Cerkve. Tako se je konec koncev le zgodilo tisto, česar nikakor ni želel. Zvestoba lastnemu prepričanju mu je pripravila navidezen polom, a prav zaradi tega navideznega poloma so se njegove misli tem bolj uveljavile in postale last evropske duhovne dediščine. Friedrich Heer $(1965,245)$ zato upravičeno pravi o njem:

Luther ima v nemškem narodu isto mesto, kakor ga imata Frančišek in Ivana Arška v svojih narodih. Ta prinašalec rešenja iz ljudstva in za ljudstvo je sin nemške stiske, nezaupanja in sovraštva do karolinške in "zahodne» gospodovalne Cerkve, ki se ji ni posrečilo, da bi to stisko razpršila in spremenila v odkrito zaupanje, predanost "vsega človeka» (totus homo: središčni Luthrov pojem) Bogu Očetu, ki pravi: »Jaz sem tvoj Bog«. [...] Vera je za Luthra isto kakor »eksistenca, ki je v celoti izročena Očetu Jezusa Kristusa« [...]. Luther je padel kakor teološka atomska bomba na deželo.

O tej »teološki atomski bombi« hočem tedaj ob 50o-letnici Luthrovega rojstva nekoliko razmisliti in se ustaviti predvsem ob tistih njenih učinkih, ki se v začetku Luthrovega delovanja še niso niti prav pokazali, ali je celo bila podoba, da bodo drugačni, kakor so potem $\mathrm{v}$ resnici bili.

\section{Luther kot utemeljitelj verskega personalizma}

Luthrova teološka misel in njegovo življenje sta odsev njegovega osebnega verskega izkustva. In prav zaradi tega mu ni mogoče odrekati njegove globoke religioznosti. Nenehno se je ustavljal ob misli na Boga, ki se je hkrati povsem prepletala z mislijo na Jezusa Kristusa, učloveče- 
nega Boga in Odrešenika. Zato Luther ni toliko razmišljal o Bogu, kakršen je sam v sebi, temveč se je ustavljal ob njem, kolikor je Bog za nas. Šlo mu je tedaj za oseben odnos med Bogom in človekom in človekom in Bogom. Prav to pa pomeni, da je njegova vera bila resnično osebna. Spoznanje Boga in priznavanje ali celo dokazovanje njegovega bivanja še ni vera. Vera je bivanje človeka $v$ Bogu, v zaupanju v Božje usmiljenje in v Božjo ljubezen, bivanje človeka kot Božjega otroka v moči Božjega Duha.

Če je tedaj srce postalo pravično po veri v njegovo ime, potem jim da Bog moč, da postanejo Božji otroci, v tem, ko jim takoj vlije svojega Svetega Duha v njihova srca, ki jih po ljubezni naredi sproščene, mirne in vesele, vršilce vsega dobrega, zmagovalce nad hudim, da, tudi preziralce smrti in pekla. Tukaj takoj prenehajo vsi zakoni in dela vseh zakonov. Sedaj je vse svobodno, postava je spolnjena v veri in ljubezni. (Luther $\mathrm{v}$ Hirsch 1964, 118-119)

Luther se tako približa misli Avguština, ki vidi v ljubezni najzanesljivejšo usmerjevalko življenja v duhu Božje postave, tako da človek sproščeno spolnjuje Božjo voljo in zato »lahko dela, kar hoče«. V resnici gre za zasidranost človeka v Bogu, ki je ljubezen, gre za življenje človeka, ki je sicer grešnik, ki pa v zaupanju v Odrešenika in z njegovo pomočjo premaguje greh, če res živi iz vere. Vera človeka opravičuje in mu daje moč za življenje. To pa je tudi evangeljski nauk, posebej pa nauk apostola Pavla, ki nasproti postavi/zakonu postavlja vero v Jezusa Kristusa in njegovo odrešujočo milost. »Pravični bo živel iz vere.« (Rim 1,17) Te misli so prinesle Luthru tolažbo, veselje in sproščenost. Takole izjavlja (v Pesch 1982, 83):

Kakor sem prej izraz »Božja pravičnost« na vso moč sovražil, tako sem sedaj z vročo ljubeznijo isti izraz kot sladak in prijeten nad vse druge povzdigoval.

Luther je prišel do spoznanja, ki mu je pokazalo možnost, da v zaupanju v Boga premaguje strah pred Bogom, ker se tako Božja pravičnost razodeva kot Božje usmiljenje. Upravičuje pa človekovo zaupanje v Boga Jezus Kristus, učlovečeni Bog, ki je vzel nase človekovo usodo, ki se je 
solidariziral s človekom in zadostil za njegove grehe. Poslej je človek res lahko človeški in sme kljub svoji grešnosti upati. Je sicer vedno »simul iustus et pecator «, a je hkrati na potu k resnični, popolni pravičnosti v Bogu, če le res veruje in se da voditi Božji ljubezni ter zaupanju v usmiljenega Boga. Personalistično razumevanje vere je tako hkrati eksistencialno in eksistencielno.

Nikakor pa ne gre v tem primeru za nekakšen subjektivizem v običajnem pomenu. Luther namreč ponovno naglaša, da je vera iz poslušanja. Zato tudi pripisuje Svetem pismu in oznanjevanju Božje besede izreden pomen. Ne učenje Cerkve, temveč Sveto pismo je pravilo človekove vere. Človek mora sam priti do spoznanja, da je Božja beseda tisto, kar veruje ali izpoveduje v veri. In to je potem tudi razlog, zakaj veruje. Tako postavlja Luther edino avtoriteto, ki se ji mora človek v veri ukloniti, in to je avtoriteta Boga, Jezusa Kristusa, Božje Besede. Bog človeku po Svetem pismu neposredno govori in mu daje spoznanje, omogoča razumevanje Božje skrivnosti v srcu. Iz tega pa seveda ne sledi, da bi bilo oznanjevanje tistih, ki so poklicani v službo besede, odveč, ne, le avtoritete nima nihče, ki bi bila enaka avtoriteti Božje besede, delovanju Božjega Duha po Božji besedi v človeškem srcu. Sem spada tudi znana Pavlova izjava: »Vse pa, kar ni iz prepričanja, je greh.» (Rim 14,23) Gre tedaj res za oseben odnos, oseben stik med človekom in Bogom po veri. Tak stik je nekaj notranjega in ga more vzpostaviti samo Bog. Luthrovo razumevanje vere je v resnici izkustveno poglobljeno, zato je razumljivo, da je vedno znova iskal navdih za svoja razmišljanja in razlago vere pri mistikih. Zopet pa ne moremo reči, da bi Luther preziral pomen del, ki naj bi izhajala iz vere. Takole pravi (v Hirsch 1964, 122):

Priznavamo, da morajo dobra dela slediti veri, bolje povedano, da ji sama po sebi sledijo, ne pa, da ji morajo slediti, saj tudi za dobro drevo velja, da prinaša dobre sadove, ne pa, da jih mora prinašati.

Luther tedaj tako resno jemlje vero, da se mu zdi življenje, ki ustreza veri, samo po sebi razumljivo. Takšna je, kratko povedano, resnično osebna vera. 
Drugi vatikanski cerkveni zbor je dal razumevanju vere podobne poudarke. V dogmatični konstituciji o Božjem razodetju (BR 1966, 5) beremo:

Bogu, ki se razodeva, smo dolžni "poslušnost vere» (Rim 16,26; prim. Rim 1,5; 2 Kor 10,5-6), s katero se človek svobodno ves izroči Bogu, ker izkazuje Bogu, ki se razodeva, "popolno pokorščino razuma in volje« in svobodno pritrdi njegovemu razodetju. Da pa pride do take vere, je potrebna predhodna in pomagajoča Božja milost ter notranja pomoč Svetega Duha, ki nagiba srce in ga obrača k Bogu, odpira duhovne oči in daje »vsem prijetnost v soglašanju z resnico in v veri vanjo«. Isti Sveti Duh tudi stalno s svojimi darovi spopolnjuje vero, kolikor globlje postaja spoznanje razodetja.

Je pa seveda ta opis vere nekoliko drugačen od tistega, ki ga najdemo $\mathrm{v}$ dokumentih prvega vatikanskega cerkvenega zbora.

Za teološko misel in njen razvoj je imelo in ima osebnostno in eksistencialno razumevanje vere, kakor ga je zagovarjal Luther, izreden pomen. Živo versko izkustvo, ki je na tak način včlenjeno v vero in razmišljanje o njej, daje veri trajno relevantnost in spodbuja teološko misel k vedno novemu poglabljanju, k vedno novim spoznanjem in smernicam za praktično življenje ter ravnanje po evangeliju, v službi človeka in sveta. To se je pokazalo v katoliški Cerkvi tudi po drugem vatikanskem cerkvenem zboru. Nasprotno pa objektivistično in intelektualistično razumevanje vere onemogoča njeno relevantnost in v veliki meri ovira razvoj teološke misli. Zato smemo reči, da je imela Luthrova misel kljub marsikateri nedorečenosti velik pomen za vse krščanstvo. Tudi katoliška Cerkev mora biti Luthru hvaležna zanjo in njene spodbude.

\section{Svoboda krščanskega človeka}

Luther je v nasprotju do postave posebej poudarjal evangeljsko svobodo. Na spis, ki je v njem razvijal to svojo misel, je bil vedno ponosen. V njem je gledal svoje izvirno delo. Naslonil pa se je tudi v tem pogledu na apostola Pavla in Avguština. Misel o krščanski svobodi je v res- 
nici najtesneje povezana $\mathrm{z}$ njegovim razumevanjem vere, ki smo se ga že dotaknili.

Po veri postane človek »nova stvar«, postane »duhoven, notranji, nov človek«. Zato opravlja tudi dela, ki mu jih vera narekuje. Opravlja jih tako, da ne čuti, kakor da bi mu jih kdo od zunaj naložil, temveč jih opravlja $\mathrm{z}$ veseljem, sproščeno in svobodno.

Dobra dela ne naredijo moža dobrega, temveč dober mož opravlja dobra dela. Hudobna dela ne naredijo moža hudobnega, temveč hudoben mož opravlja hudobna del. Tako mora vedno biti bitje dobro ali biti oseba dobra pred vsemi dobrimi deli in dobra dela potem izhajajo iz dobre osebe. (Luther 1983, 29)

Luther jemlje vero res zelo resno kot stik z Bogom, kot milost, kot učinek Božje dejavnosti, ki človeka opravičuje in mu daje posebno moč, da živi iz vere ali opravlja dobra dela, kakršna mu vera narekuje in omogoča.

Tako, glej, izvirata iz vere ljubezen in veselje v Gospodu, iz ljubezni pa vedra, vesela in svobodna misel, da človek služi bližnjemu brez ozira na hvaležnost ali nehvaležnost, hvalo ali grajo, dobiček ali izgubo. (Luther $1983,10)$

In v tem je sproščenost, je svoboda kristjana. Luther potem poveže svetopisemsko svobodo s služenjem. Zato postavi znano načelo (str. 9):

Kristjan je povsem svoboden gospodar nad vsem in ni nikomur podložen. Kristjan je vdan služabnik in vsakemu podložen.

Ker kristjanova svoboda izvira v resnici iz njegove vere, ki včlenjuje ljubezen in ponižnost kot sestavnici novega življenja v Jezusu Kristusu in po njem, je razumljivo, da je krščanska svoboda hkrati ljubezenska služba, da je služenje, da je hkrati tudi gospodovanje in vdana služba.

Te Luthrove misli so pomembne za duhovno življenje sploh, posebno pa še za pravilno razumevanje krščanske morale. Ne gre za spolnjevanje nekih predpisov ali zakonov, ki naj bi ga kristjan jemal nase kot breme, temveč gre za pripravljenost, da se da voditi Božjemu Duhu, da se odpre Bogu in tako pusti ljubezni prosto pot in možnost delovanja. 
Človek je namreč tem bolj svoboden, čim bolj se odpre svoji presežni razsežnosti, čim bolj se odpre Bogu, kajti tako mu je dana možnost resnične izbire, gospostva nad seboj in sproščenosti. Hkrati pa se to pravi, da se človek odpre za »zakon« ali "postavo« ljubezni, ki pa v resnici ni zakon niti postava, temveč svobodno odločanje, za katero nas je oprostil Kristus, kakor pravi apostol Pavel (prim. Gal 5). Vsekakor so te Luthrove misli povsem svetopisemsko utemeljene, saj beremo v Pavlovih pismih tudi besede: »Kjer pa je Duh Gospodov, tam je svoboda.« (2 Kor 3,17) In tako je tudi duhovnost, ki jo nakazujejo te misli, res svetopisemska, duhovnost resnice, ki osvobaja, kakor pravi Kristus (Jn 8,31):

Če boste v mojem nauku vztrajali, boste zares moji učenci: spoznali boste resnico in resnica vas bo osvobodila.

Morala pa, ki jo utemeljujejo iste osnove, nima več nič skupnega $\mathrm{z}$ juridizmom, temveč je res evangeljska morala, ki sloni na veri v Jezusa Kristusa in pomeni hojo za Kristusom, svobodo v Kristusu, poslušnost Duhu, ki je človeku dan »tisto uro", ko se odloča. Ti pogledi danes določujejo tudi katoliški moralni nauk.

Ob tem razmišljanju bi se zopet lahko ustavili pri marsikateri misli, ki jo najdemo $v$ dokumentih drugega vatikanskega cerkvenega zbora in ki potrjuje Luthrova spoznanja. Predvsem pa se moramo nehote spomniti nasprotnih pogledov, ki so se dolgo časa uveljavljali v Cerkvi in jih je pisatelj Dostojevski naslikal v Velikem inkvizitorju. Ob podobi velikega inkvizitorja še bolj spoznamo pomen Luthrovih nazorov o svobodi krščanskega človeka. Žal je seveda res, da Luther iz različnih razlogov ni bil in ni mogel biti dosleden $v$ tem svojem spoznanju in presojanju ravnanja, ki je iz njega sledilo. Münzerjev primer je že sam zgovorna priča za to. A rekli bi lahko, da se plamen, ki je zagorel po Luthrovi zaslugi, naj je on to hotel ali ne, kljub temu ni dal več pogasiti. Osvobajajoča prizadevanja in gibanja $\mathrm{v}$ zgodovini so se po Luthru navdihovala tudi iz njegovega poudarjanja krščanske svobode.

Nedvomno je tedaj, da ima Luther velike zasluge za to, da se je kljub toliko oviram naposled le uveljavila svobodna človekova misel in je premagala vse poskuse, ki so jo znova in znova hoteli zatreti. Njegovo po- 
udarjanje krščanske svobode je prispevalo svoj delež tudi k vedno večji zrelosti vernikov in $\mathrm{k}$ zavesti njihove odgovornosti za Cerkev celo v katoliških vrstah. Zrelost pa pomeni rast, razvoj, življenje. Zrelost pomeni zmago avtoritete resnice nad resnico avtoritete. Zrelost pomeni humanizem, ki ga je tedaj Luther pospeševal, čeprav je zaradi svoje preroške odločnosti in zavzetosti za prenovo Cerkve, za zmago čistega evangelija ponovno prišel v spor s takratnimi humanisti. Svoboda, ki jo je Luther oznanjal, je bila velik dar krščanstvu in človeštvu nasploh.

\section{Demokratična Cerkev}

Luther se je v svojem prizadevanju za reformo Cerkve kot institucije naslanjal predvsem na Sveto pismo. Zato cerkvene institucije ni odklanjal, pa če je bil še tako razočaran nad rimsko Cerkvijo. Hotel je preprosto tej Cerkvi vtisniti tisto podobo, ki naj bi ustrezala evangeliju. Hotel je za takšno reformo pridobiti tiste, ki jih je imel za posebej odgovorne za Cerkev. Ker pa njegovo prizadevanje ni našlo odmeva, je tem ostreje nastopal zoper nepravilnosti v življenju Cerkve in hkrati kazal na novo podobo, ki naj bi jo dobila.

Luther je razlikoval med zunanjeinstitucionalno Cerkvijo in njeno globljo vsebino ali razsežnostjo. Govoril je tudi o »duhovnem notranjem krščanstvu« in »telesnem zunanjem krščanstvu« (Pesch 1982, 207, op. FKV). Pozneje je poudarjal predvsem skrivnostno naravo Cerkve. Zato je po njegovem prepričanju nemogoče ugotoviti, kdo v resnici po Božji sodbi pripada Cerkvi. Cerkev »je v mesu in se v mesu razodeva, a vendar ni meso; je v svetu in jo je v svetu mogoče zaznati, a vendar ni svet « (Pesch 1982, 208, op. FKV).

Nikakor pa Luther ni priznaval samo skrite, notranje Cerkve, temveč je želel samo, da bi ta razsežnost Cerkve bila čim bolj navzoča in bi se čim bolj uveljavila v vidni, zunanji Cerkvi, da ta ne bi bila kriva Cerkev. Hotel je tedaj doseči, da se institucija ne bi uveljavljala na račun oznanjevanja Božje besede in resnične, prave vere.

Kratko je Luther opredelil Cerkev kot »skupnost takšnih ljudi, ki so kristjani in sveti«, kot »krščansko sveto ljudstvo, ki veruje v Kristusa «. (Pesch 1982, 209) Poudarek je na ljudstvu, zato je izključeno "pirami- 
dalno« razumevanje Cerkve, ki pozna predvsem papeža, škofe in duhovnike, kadar je govor o Cerkvi. Ljudstvo, verniki ali laiki so namreč v skladu s takšnim piramidalnim razumevanjem Cerkve le njeni pasivni člani, ki morajo samo poslušati vodstvo in se mu dati v vsakem pogledu voditi, učiti.

Razumljivo je, da potem Luther posebej govori o splošnem duhovništvu, ki so ga po krstu deležni vsi verniki. Čeprav pa je tako vsak vernik sam po sebi usposobljen za službo besede in zakramenta v Cerkvi, so vendar zaradi reda za opravljanje te službe potrebni posebni služabniki, ki to postanejo po pozivu cerkvene občine in »ordinaciji«.

Iz povedanega sledi, da je Cerkev, kakršno si želi Luther, predvsem bratska skupnost, kakršna je bila $\mathrm{v}$ začetku, kakršno nam slikajo Apostolska dela. Sicer pa je Kristus sam nakazal, kakšna predvsem naj bo njegova Cerkev. Apostolom je namreč govoril takole (Mt 23,8-10):

Vi se pa ne dajte klicati z imenom »rabbi«, zakaj eden je vaš Učenik, vi vsi ste pa bratje. Tudi ne kličite nikogar na zemlji »očeta«, zakaj eden je vaš Oče, tisti, ki je v nebesih. Tudi se ne imenujte vodnik, zakaj eden je vaš vodnik, Kristus.

In tako bi smeli upravičeno reči, da gre za demokratično urejeno cerkveno institucijo, ki naj bi bila čim bolj Kristusova, ne pa čim bolj »cerkvena«.

Čeprav je v katoliški Cerkvi na drugem vatikanskem cerkvenem zboru nekoliko prišlo do premikov v isti smeri, najbrž vseeno govor o Cerkvi kot "zakramentu« ni približal katoliškega pojmovanja Cerkve Luthrovemu. Razen tega tudi ne smemo pozabiti učenja prvega vatikanskega cerkvenega zbora, ki je še posebej poudaril Cerkev kot vidno in popolno družbo, kot institucijo, česar drugi vatikanski cerkveni zbor ni preklical. Tukaj se v resnici srečujeta dva pogleda, dve drži: medtem ko Luther hoče, da bi bila Cerkev, kar se tiče njenih struktur, čim bolj preprosta, "strukturalno uboga«, hoče biti katoliška Cerkev tudi strukturalno čim popolnejša in vsestransko urejena skupnost (Maron 1982, 60). Zato pa imamo v katoliški Cerkvi še vedno opraviti s trdno hierar- 
hično zgradbo Cerkve in se pravice vernikov v njej večkrat le s težavo uveljavljajo.

Luthrovo razumevanje Cerkve je izziv za krščanstvo sploh, posebno še za vzhodno - pravoslavno Cerkev in za katoliško Cerkev. Tega izziva se kljub vsemu ne da prezreti, in tako Luthrove pobude tudi v tem pogledu niso ostale brez odmeva v teh Cerkvah. Sicer pa prav tako splošen razvoj človeštva in človeške misli vedno bolj onemogoča avtoritarnost v Cerkvi, ki ji je njena hierarhična zgradba sama po sebi naklonjena. Ker takšen razvoj pomeni hkrati približevanje evangeliju, lahko tem bolj cenimo Luthrovo preroško spoznanje in prizadevanje.

Luthrova »demokratična podoba« Cerkve pa je nedvomno vplivala na razvoj človeške družbe sploh, čeprav je v začetku naletela na nerazumevanje in je niti Luther ni upal dosledno zagovarjati, še manj pa pospeševati zmago demokratičnega duha v svetni družbi. Toda »ogenj je bil vržen na zemljo« tudi v tem primeru, čeprav se njegove posledice niti malo niso takoj pokazale v vsem obsegu.

\section{Sklepna beseda}

S treh strani smo si ogledali podobo reformatorja Martina Luthra, kakršna odseva iz njegove reformatorske misli. Osebna vera, krščanska svoboda in bratstvo ali demokratičnost cerkvene skupnosti so sestavnice Luthrovih teoloških pogledov, ki so bile pomembne za njegove reformatorske cilje, ki so se uveljavile v protestantizmu in so sčasoma postale last krščanskih skupnosti ter Cerkva sploh. Zato danes po toliko stoletjih tudi katoliška Cerkev zna ceniti Luthrovo delo. Katoliški teologi in cerkveni pisatelji ne gledajo na Luthra več tako pristransko, kakor se je to dogajalo dolga stoletja. Vedno bolj se uveljavlja prepričanje, da mora tudi katoliška Cerkev biti za marsikaj hvaležna Luthru in njegovemu delu, čeprav ga je za časa življenja izobčila in ni našla razumevanja zanj, vsaj ne v tisti meri, kakor bi si zaslužil. Zelo počasi in večkrat prav sramežljivo je tudi uradna katoliška Cerkev sprejemala nekatera njegova spoznanja in spodbude, njegove navdihe in tako pripravljala pot današnji Luthrovi podobi v katoliških vrstah. Bolje je vsekakor, da je do te spremembe prišlo, četudi pozno, kakor če bi ne prišlo nikdar. Velike 
zasluge za to ima nedvomno drugi vatikanski cerkveni zbor, čeprav se je razvoj v isti smeri začel že prej in bi lahko imenovali marsikaterega teologa ali cerkvenega pisatelja, ki si je prizadeval za resničen, pristen duhovni lik velikega reformatorja.

Ekumensko gibanje je nedvomno veliko storilo tudi za pozitivne poglede na Luthra in njegovo delo, za njegovo pravično vrednotenje. Zato so razumljive besede njegovega voditelja v katoliški Cerkvi kardinala Willebrandsa (v Fuchs 1982, 63):

Kdo bi mogel danes tajiti, da je bil Luther globoko religiozna osebnost, da je iskreno in vdano raziskoval evangeljsko sporočilo? Kdo bi mogel zanikati, da je ohranil pomemben zaklad stare katoliške vere, čeprav je nadlegoval rimskokatoliško Cerkev in Apostolski sedež?

Reformacija je vsekakor tudi katoliška zadeva, saj je tudi katoliška Cerkev odgovorna za vse, kar se je zgodilo, ne da bi Luther to hotel, in je prav tako izzvala njegov upravičen nastop.

Rekli bi lahko, da je katoliška Cerkev sedaj tudi poklicana k spravi z Luthrom, se pravi, da je njena dolžnost sprejeti bogastvo Luthrove teološke misli in njene posledice, kolikor jih zahtevajo danes tudi znamenja časa. Sem spada med drugim vse tisto, kar se danes prebuja v cerkveni bazi, v različnih skupinah, in nakazuje novo prihodnost resnično angažirane Cerkve.

Luther ima še po 500 letih katoliškemu teologu veliko povedati, če mu ta le brez predsodkov prisluhne.

\section{LITERATURA}

BR = Drugi vatikanski koncil (1962-1965). 1966. Dogmatična konstitucija o Božjem razodetju: slovenski prevod. Ljubljana: Nadškofijski ordinariat.

Fuchs, H. Ottmar. 1982. "Zum Lutherbild in der neueren römisch-katholischen Theologie."V Martin Luther: Beitrag der CDU zum 50o. Geburtstag des Reformators. Bonn: CDU.

Heer, Friedrich. 1965. Europäische Geistesgeschichte. Stuttgart: Kohlhammer.

Hirsch, Emanuel. 1964. Hilfsbuch zum Studium der Dogmatik. Berlin: Walter de Gruyter. 


\section{BILO JE POVEDANO}

Luther, Martin. 1983. Die reformatorische Grundschriften 4: Die Freiheit eines Christen. München: DTV.

Maron, Gottfried. 1982. Das katholische Lutherbild der Gegenwart. Göttingen: Vandenhoeck \& Ruprecht.

Pesch, Hans Otto. 1982. Hinführung zu Luther. Mainz: Grünewald.

Zahrnt, Heinz. 1977. Warum ich glaube: Meine Sache mit Gott. München: Piper. 